\title{
Flood Frequency Analysis at the Downstream of Sg. Perak River Basin using Annual Maximum Flow Discharge Data
}

\author{
Munir Snu ${ }^{1 *}$, Sidek L.M ${ }^{2}$, Haron $\mathrm{Sh}^{3}$, Noh Ns.M ${ }^{4}$, Basri H. ${ }^{5}$, M.Marufuzzaman ${ }^{6}$, Hafiz Z.M. $^{7}, \operatorname{Razad}_{\text {Az.A }}{ }^{8}$ \\ ${ }^{1}$ Civil Engineering Department, College of Engineering, Universiti Tenaga Nasional, Malaysia \\ ${ }_{2}^{2}$ Sustainable Technology \& Environment Group, Institute for Energy Infrastructure Universiti Tenaga Nasional, Kajang, \\ Selangor \\ ${ }^{3}$ Tenaga Nasional Berhad Research (TNBR), No.1, Lorong Air Hitam, Kawasan Institusi Penyelidikan, Kajang, Selangor, \\ *Corresponding author E-mail: mimiemunir@gmail.com
}

\begin{abstract}
The recent flood event occurred in 2014 had caused disaster in Perak and Sungai Perak is the main river of Perak which is a major natural drainage system within the state. The aim of this paper is to determine the expected discharge to return period downstream for Sg. Perak River Basin in Perak by using annual maximum flow data. Flood frequency analysis is a technique to assume the flow values corresponding to specific return periods or probabilities along the river at a different site. The method involves the observed annual maximum flow discharge data to calculate statistical information such as standard deviations, mean, sum, skewness and recurrence intervals. The flood frequency analysis for Sg. Perak River Basin was used Log Pearson Type-III probability distribution method. The annual maximum peak flow series data varying over period 1961 to 2016 . The probability distribution function was applied to return periods $(\mathrm{T})$ where $\mathrm{T}$ values are 2years, 5years, 10years, 25years, 50years, and 100years generally used in flood forecasting. Flood frequency curves are plotted after the choosing the best fits probability distribution for annual peak maximum data. The results for flood frequency analysis shows that $\mathrm{Sg}$. Perak at Jambatan Iskandar much higher inflow discharge which is $3714.45 \mathrm{~m}^{3} / \mathrm{s}$ at the 100years return period compare to $\mathrm{Sg}$. $\mathrm{Plus}$ at $\mathrm{Kg}$ Lintang and Sg. Kinta at Weir G. With this, the 100years peak flow at Sg Perak river mouth is estimated to be in the range of 4,000 m3/s. Overall, the analysis relates the expected flow discharge to return period for all tributaries of Sg. Perak River Basin.
\end{abstract}

Keywords: Flood frequency analysis; maximum peakflow; discharge; return period.

\section{Introduction}

Flood disasters are among the world is most common, damaging types of disaster and unexpected natural events causing misfortune of lives and harm to public property. In fact, it becomes the most important natural disaster in term of the population affected, frequency, financial cost and the disruption of socio-economic activities. [1] Different states in Malaysia, the flood has become a common disaster because it happened almost every year. The northeast monsoon usually happened between November and February caused the heavy rainfall as much as $610 \mathrm{~mm}$ in 24 hours in ultimate cases primarily in the east coast of Peninsular Malaysia and to Sabah and Sarawak. Usually, flood happened from November to January when the northeast monsoon leads a large volume of runoff to the relatively large catchment areas. [2-3] Furthermore, climate change and variability have caused significant impacts on the hydrological cycle (flood and drought) as well as affecting the overall level of water availability in an urban city. [47] Flood frequency analysis is the most explicit method for determine the design flood which is very important part in the floodplain management, development and planning controls, and in the design of hydraulic structures. Usually, In Malaysia, a 100years ARI has been used for designing hydraulic structures. [9] In reducing the disaster risk and to effectively protect people, goods and infrastructures, is important to appraise and map the natural hazard on the element of any natural disaster using Flood frequency analysis technique.

The purpose of using flood frequency analysis is to connect flood intensity with its probability of exceedance which represent the discharge and return period respectively. This information is important for divergent operational applications such as prevention of flood or civil engineering design including dams, dykes, any construction near a river. [9] The heavy and continuous rainfall will exceeding the absorptive capacity of the soil, and the flow capacity of the streams caused high flow exceeding danger levels and entering in floodplains. This event will causes damage to property and life in different parts of the catchment. [12] Previous studies have also been done to estimate flood based on catchment characteristics and statistical analysis by using at least 30 to 40 years of records data. The short data records and also missing data then regional flood frequency curves together provide consistent estimates of floods. [12] Moreover, the water availability, catchment characteristics and also possible extreme hydrological conditions like floods and droughts at different locations of the river system may be shown through the flood frequency analysis. [9] The flood frequency analysis was using the observed annual maximum flood data from gauging station to measure flood magnitude. [10] Statistical distribution method is needed for the purpose of when a long period of recorded flood data required [11].

The Log-Pearson Type III distribution is a statistical technique to assume the design flood for a different site of the river using the fitting frequency distribution data. The frequency distribution will 
be established when the statistical information is calculated for the river site. The different sizes of probabilities of floods can be extracted from the curve. The advantage of this technique is that extrapolation can be formed using the value from the events with return periods exceed the observed flood events. The Federal Agencies in the United States also using this technique. [13] The purpose of the paper is to determine the expected discharge to return period downstream for Sg. Perak River Basin in Perak by using annual maximum flow data.

\section{Study Area}

Sg. Perak River is the main river in Perak which covers a catchment area of $3504 \mathrm{~km}^{2}$ and river length approximately $400 \mathrm{~km}$, flowing from Hulu Sg. Perak at upper of Temengor catchment through Bagan Datoh until Strait of Malacca. Sg. Perak is the second largest river in Peninsular Malaysia after Sg. Pahang. Figure 1 shows the overall catchment of Sungai Perak river basin. The annual rainfall is in the range of $2400 \mathrm{~mm}$ to $3200 \mathrm{~mm}$ at the northeast part of the basin, particularly in the upper Temenggor Dam catchment. At the south-eastern part of the basin, the annual rainfall increases between $2,600 \mathrm{~mm}$ and $3,400 \mathrm{~mm}$. The average annual rainfall for the whole basin is about $2,300 \mathrm{~mm}$. (IRBM, 2010) Figure 1 shows the Sg Perak Basin Catchment Delineation for Rainfall-Runoff Model.

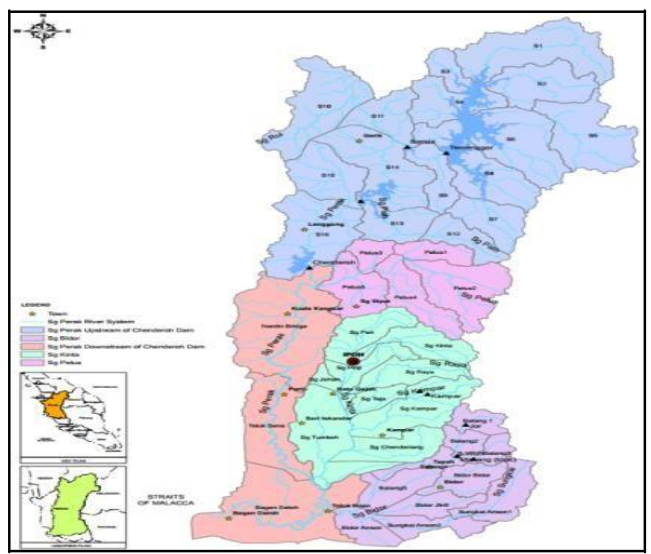

Fig. 1: Sg Perak Basin Catchment Delineation for Rainfall-Runoff Model (source: G\&P, 2010).

\section{Methodology}

Flood frequency analysis is used to assume design floods for sites along a river using the observed annual maximum flow discharge data to calculate statistical information such as mean values, standard deviations, skewness, and recurrence intervals. Then, it used to construct frequency distributions, which are graphs and tables that tell the probability of different discharges as a function of recurrence interval or exceed probability. Flood frequency distributions are divided into four (4) method. Four of the common methods are:
a. Normal Distribution
b. Log-Normal Distribution
c. Gumbel Distribution
d. Log-Pearson Type III Distribution

The method of data collecting is using Tideda where the real data through the installation of standard meteorological stations which belongs to government agencies and others agencies related. [8] Hydrological data of Malaysia is supports in both manual and automatic system by the Department of Irrigation and Drainage (DID) and other government agencies such as Tenaga Nasional Berhad (TNB) and other agencies.

The available manual and auto logger type streamflow stations for DID in Perak, total up to 34 units of stations. The rainfall stations for TNB are two units of stations. Figure 2 shows the location of streamflow stations accordingly to its coordinates.

By reviewing the stream flow data collection in Sg. Perak Hydroelectric Scheme, a decision regarding the selection of appropriate and suitable rainfall stations that can be used for this study was done. The available longest records data should be at least up to 10 years. Table 1 shows the selected streamflow stations in this study and figure 3 shows the Analysis Technique on Flood Frequency Analysis using Log-Pearson Type III Distribution. For DID station, the stream flow recording stations available in the study from the year open up to the year 2016. There were two (2) TNB's stream flow recording stations available in the study area. However, both stations were closed in the year 1982 and 1996.

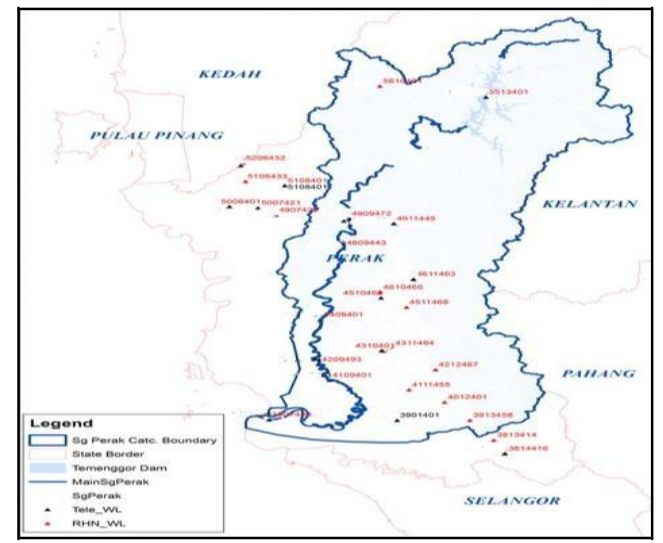

Fig. 2: Location of available streamflow stations located in the State of Perak

Table 1: List of DID and TNB Stream flow Station

\begin{tabular}{|l|c|l|c|}
\hline No. & Station No. & \multicolumn{1}{|c|}{ Station Name } & Owner \\
\hline 1. & 3913458 & Sg. Sungkai at Sungkai & DID \\
\hline 2. & 4012401 & Tg. Bidor at Malayan Bidor & DID \\
\hline 3. & 4111455 & Sg. Btg. Padang at Tg. Keramat & DID \\
\hline 4. & 4212467 & Sg. Chendering at Bt. 32 Jalan Tapah & DID \\
\hline 5. & 4310401 & Sg. Kinta at Weir G at Tg. Tualang & DID \\
\hline 6. & 4311464 & Sg. Kampar at Kg. Lanjut & DID \\
\hline 7. & 4511468 & Sg. Raia at Keramat Pulai & DID \\
\hline 8. & 4610466 & Sg. Pari at Jln. Salibin & DID \\
\hline 9. & 4611463 & Sg. Kinta at Tg. Rambutan & DID \\
\hline 10. & 4809443 & Sg. Perak at Jambatan Iskandar & DID \\
\hline 11. & 4911445 & Sg. Pelus at Kg. Lintang & DID \\
\hline 12. & 5610401 & Sg. Rui at Jambatan Jalan Raya & DID \\
\hline 13. & 6011 & Sg. Perak at Kuala Temain & TNB \\
\hline 14. & 6029 & Sg. Piah at Kuala Chenderoh & TNB \\
\hline
\end{tabular}

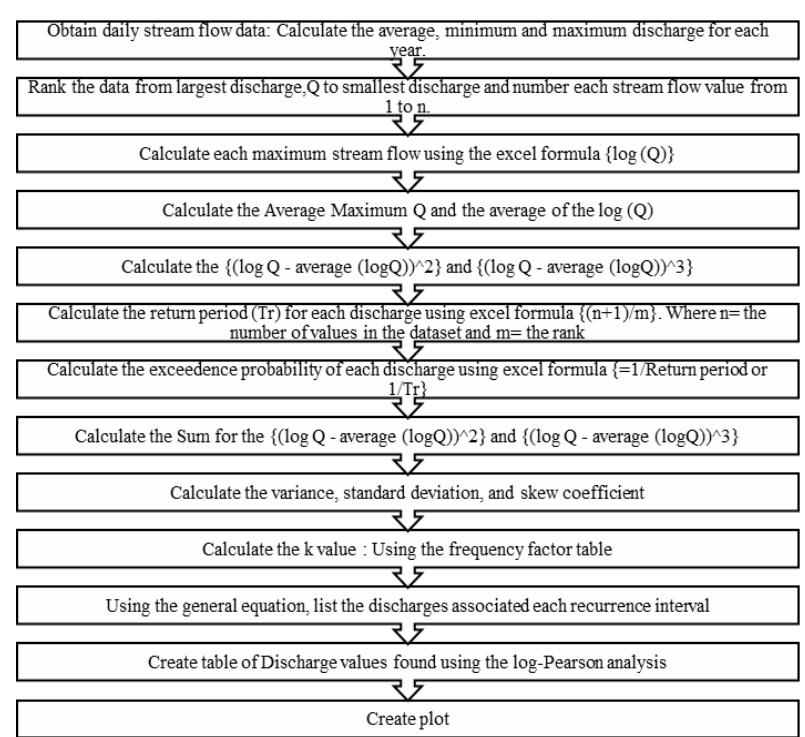

Fig. 3: Analysis Technique on Flood Frequency Analysis using LogPearson Type III Distribution. 


\section{Results and Discussion}

Flood frequency analysis was also carried out at all selected stream flows stations including $\mathrm{Sg}$ Pelus at $\mathrm{Kg}$ Lintang and $\mathrm{Sg}$ Kinta at Weir G, which are the major tributaries of Sg Perak. Table 2 shows the summary of the flood frequency analysis results.

\begin{tabular}{|c|c|c|c|c|c|c|c|}
\hline \multirow{2}{*}{$\begin{array}{c}\text { Station } \\
\text { No. }\end{array}$} & \multirow{2}{*}{ Station Name } & \multirow{2}{*}{\begin{tabular}{|l|} 
\\
Years
\end{tabular}} & \multicolumn{5}{|c|}{ Peak Flows (m3/s) } \\
\hline & & & $\begin{array}{l}\mathbf{Q} \\
\mathbf{2}\end{array}$ & $\begin{array}{l}\mathbf{Q} \\
5\end{array}$ & \begin{tabular}{|c|}
$Q$ \\
25 \\
\end{tabular} & \begin{tabular}{|c|}
$\mathbf{Q}$ \\
$\mathbf{5 0}$
\end{tabular} & $\begin{array}{c}Q \\
100\end{array}$ \\
\hline 3913458 & $\begin{array}{l}\text { Sg. Sungkai at } \\
\text { Sungkai }\end{array}$ & \begin{tabular}{|l|}
$1961-$ \\
2016 \\
\end{tabular} & 52.14 & 85.27 & 131.59 & 148.92 & 165.07 \\
\hline 4012401 & $\begin{array}{c}\text { Tg. Bidor at } \\
\text { Malayan Bidor }\end{array}$ & \begin{tabular}{|l|}
$1981-$ \\
2016 \\
\end{tabular} & \begin{tabular}{|l|}
55.74 \\
\end{tabular} & 100.56 & 176.99 & 210.31 & 243.81 \\
\hline 4111455 & $\begin{array}{l}\text { Sg. Btg. } \\
\text { Padang at Tg. } \\
\text { Keramat }\end{array}$ & $\begin{array}{l}1961- \\
2016\end{array}$ & 73.71 & 104.53 & 140.34 & 152.17 & 162.54 \\
\hline 4212467 & $\begin{array}{l}\text { Sg. Chender- ing } \\
\text { at Bt. } 32 \\
\text { Jalan Tapah } \\
\end{array}$ & \begin{tabular}{|l|}
$1971-$ \\
2016
\end{tabular} & 27.19 & 41.45 & 59.35 & 65.57 & 71.13 \\
\hline 4310401 & $\begin{array}{l}\text { Sg. Kinta at Weir } \\
\text { G at Tg. } \\
\text { Tualang } \\
\end{array}$ & $\begin{array}{l}1977 \\
2016\end{array}$ & 276.36 & 411.59 & 643.93 & 750.18 & 862.53 \\
\hline 4311464 & $\begin{array}{l}\text { Sg. Kampar at } \\
\text { Kg. Lanjut }\end{array}$ & \begin{tabular}{|l|}
$1961-$ \\
2016 \\
\end{tabular} & 32.89 & 67.41 & 147.41 & 191.69 & 242.88 \\
\hline 4511468 & $\begin{array}{c}\text { Sg. Raia at } \\
\text { Keramat Pulai }\end{array}$ & \begin{tabular}{|l|}
$1978-$ \\
2016 \\
\end{tabular} & 28.31 & 65.10 & 132.11 & 160.72 & 188.63 \\
\hline 4610466 & $\begin{array}{l}\text { Sg. Pari at Jln. } \\
\text { Salibin }\end{array}$ & \begin{tabular}{|l|}
$1961-$ \\
2016 \\
\end{tabular} & 59.60 & 106.47 & 174.38 & 199.92 & 223.54 \\
\hline 4611463 & \begin{tabular}{|c|} 
Sg. Kinta at Tg. \\
Rambutan
\end{tabular} & \begin{tabular}{|l|}
$1961-$ \\
2016 \\
\end{tabular} & 50.94 & 92.62 & 172.43 & 210.93 & 252.12 \\
\hline 4809443 & $\begin{array}{l}\text { Sg. Perak at } \\
\text { Jambatan } \\
\text { Iskandar } \\
\end{array}$ & $\begin{array}{l}1961- \\
2016\end{array}$ & 584.49 & 1047.74 & 2191.22 & 2875.43 & 3714.45 \\
\hline 4911445 & \begin{tabular}{|l|} 
Sg. Pelus at Kg. \\
Lintang
\end{tabular} & \begin{tabular}{|l|}
$1961-$ \\
2016 \\
\end{tabular} & 95.21 & 153.88 & 235.08 & 265.31 & 293.40 \\
\hline 5610401 & $\begin{array}{c}\text { Sg. Rui at } \\
\text { Jambatan Jalan } \\
\text { Raya }\end{array}$ & \begin{tabular}{|l|}
$1987-$ \\
2016
\end{tabular} & 31.14 & 59.65 & 115.20 & 142.08 & 170.81 \\
\hline 6011 & $\begin{array}{c}\text { Sg. Perak at } \\
\text { Kuala Temain }\end{array}$ & $\begin{array}{c}1966- \\
1981 \\
\end{array}$ & 426.03 & 963.56 & 2084.19 & 2630.35 & 3207.85 \\
\hline 6029 & $\begin{array}{l}\text { Sg. Piah at Kuala } \\
\text { Chen-deroh }\end{array}$ & $\begin{array}{l}1981- \\
1995\end{array}$ & 436.42 & 965.36 & 1969.27 & 2420.61 & 2877.59 \\
\hline
\end{tabular}

The 2years and 100years peak flow for Sg Perak at Jambatan Iskandar are $584.49 \mathrm{~m}^{3} / \mathrm{s}$ and $3714.45 \mathrm{~m}^{3} / \mathrm{s}$ respectively. Sg Pelus is the largest tributary that joins Sg Perak between the Chenderoh Dam and Sg Kinta confluence. Large parts of the Pelus catchment is still dominated by forest and plantation tree crops. The 2years and 100years ARI peak flow for Sg Pelus at Kg Lintang are 95.21 $\mathrm{m}^{3} / \mathrm{s}$ and $293.40 \mathrm{~m}^{3} / \mathrm{s}$ respectively.

For Sg Kinta at Weir G, the 100years peak flow is computed to be $862.53 \mathrm{~m}^{3} / \mathrm{s}$ using frequency analysis in this Study. The remarkable increase in 100years in this study is mainly due to two recent high storm events which occurred in October $2008\left(746 \mathrm{~m}^{3} / \mathrm{s}\right)$ and January $2009\left(767 \mathrm{~m}^{3} / \mathrm{s}\right)$. The increase in peak flow could also be attributed to continuous land development activities, which have resulted in higher flood flow.

The major tributary, $\mathrm{Sg}$ Bidor with the catchment area of 1,787 $\mathrm{km}^{2}$ is located south of the Sg Kinta catchment. The 100years peak flow for $\mathrm{Sg}$ Bidor catchment could be estimated to be of the same magnitude as Sg Kinta at Tg Rambutan based on the similar catchment size. The lateral catchments along Sg Perak at the downstream of Chenderoh Dam have a total combined catchment area of $2,596 \mathrm{~km}^{2}$. Using the simple area proportional method transposed from 100years of Sg Kinta at Weir G, the combined 100years peak flow for the lateral catchment is about $1,293 \mathrm{~m}^{3} / \mathrm{s}$.
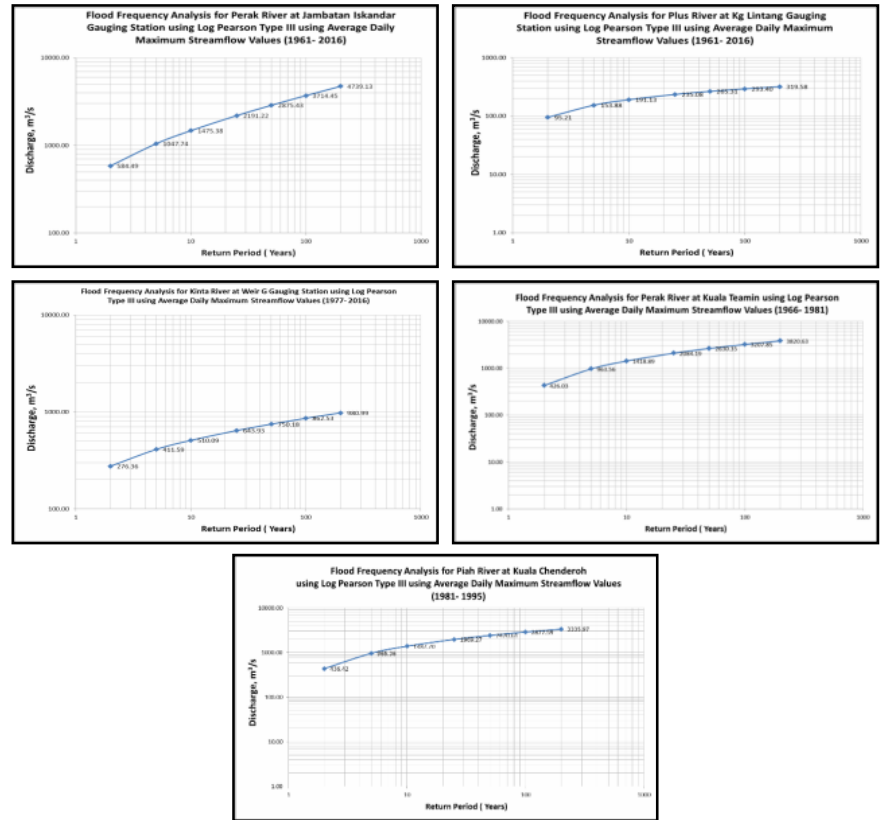

Fig. 4: Flood frequency analysis graph using Log-Pearson Type III distribution for selected stations.

\section{Conclusion}

The results for flood frequency analysis shows that Sg. Perak at Jambatan Iskandar much higher inflow discharge which is $3714.45 \mathrm{~m}^{3} / \mathrm{s}$ at the 100 years, return period compares to $\mathrm{Sg}$. Plus at $\mathrm{Kg}$ Lintang $293.40 \mathrm{~m}^{3} / \mathrm{s}$ and $\mathrm{Sg}$. Kinta at Weir G $862.53 \mathrm{~m}^{3} / \mathrm{s}$. With this, the 100years peak flow at Sg Perak river mouth is estimated to be in the range of $4,000 \mathrm{~m}^{3} / \mathrm{s}$. Overall, the analysis relates the expected flow discharge to return period for all tributaries of Sg. Perak River Basin.

The Log-Pearson Type III distribution shows the values of expected discharges from the river at different recurrence intervals based on the available historical record. It very important for designing structures in or near the river which may be affected by floods and also to protect against the largest expected event.

\section{Acknowledgement}

The authors like to acknowledge the International Centre for Water Hazard and Risk Management (ICHARM), Tenaga Nasional Berhad Research (TNBR) for their support and collaboration in making this project successful. A many thanks to a research team from the Centre for Sustainable Technology and Environment Group (STEG), Universiti Tenaga Nasional (UNITEN) give full commitment to conduct this research.

\section{References}

[1] Hafiz I., Sidek, L.M., Basri, H., Fukami, K., Hanapi, M.N., Livia, L. \& Jaafar, A.S. 2015, "Integrated flood analysis system (IFAS) for Kelantan river basin", IEEE 2nd International Symposium on Telecommunication Technologies, Article number 7238196, pp. 159162.

[2] Hafiz I, Nor N.D.M, Sidek L.M, Basri H., Hanapi M.N, Livia L, 2013, Application of Integrated Flood Analysis System (IFAS) for Dungun river basin, IOP Conference Series: Earth and Environmental Science, 16(1), Article number 012128.

[3] Che Ros F, Tosaka H, Sidek LM, Basri H., 2016, Homogeneity and trends in long-term rainfall data, Kelantan River Basin, Malaysia, Int J River Basin Management, 14(2), pp. 151-163.

[4] Jajarmizadeh M, Sidek LM, Mirzai M, Alaghmand S, Harun S, Majid MR., 2016, Prediction of Surface Flow by Forcing of Climate Forecast System Reanalysis Data, Water Resource Management, 30(8), pp. 2627-2640. 
[5] Chow MF, Abu Bakar MF, Sidek L.M, Basri H., 2017, Effects of substrate types on runoff retention performance within the extensive green roofs, J Eng Appl Sci, 12(21), pp. 5379-5383.

[6] Fai CM, Bakar MFBA, Roslan MAAB, Fadzailah FAB, Idrus MFZB, Ismail NFB, Sidek LM, and Basri H, Hydrological performance of native plant species within extensive green roof system in Malaysia. ARPN J Eng Appl Sci 2015; 10(15):6419-6423.

[7] Kok KH, Sidek L.M, Abidin MR, Basri H, Muda ZC, Beddu S., 2013, Evaluation of green roof as green technology for urban stormwater quantity and quality controls. IOP Conference Series: Earth and Environmental Science, 16(1), Article Number 012045.

[8] Lariyah, M.S., Mohiyaden, H.A., Hayder, G., Hayder, G., Hussein, A., Basri, H., Sabri, A.F. And Noh, M.N., 2016. Application of Moving Bed Biofilm Reactor (MBBR) and Integrated Fixed Activated Sludge (IFAS) for Biological River Water Purification System: A Short Review, IOP Conference Series: Earth and Environmental Science 2016

[9] N. Guru and R. Jha, Flood frequency analysis of Tel Basin of Mahanadi river system, India using annual maximum and POT flood data. Aquatic Procedia ,4, 427-434, (2015)

[10] B. P. Parida, R. K. Kachroo and D. B. Shrestha, Regional flood frequency analysis of Mahi-Sabarmati Basin ( Subzone 3-a ) using Index Flood Procedure with L-Moments. Water Resources Management, 12(1), (1998)

[11] A. Z. Ismail, Z. Yusop and Z. Yusof, Comparison of flood distribution models for Johor River basin. Jurnal Teknologi (Science and Engineering), 72(1), 1-6 (2015)

[12] A. S. Rahman, A. Rahman, M. A. Zaman, K. Haddad, A. Ahsan and M. Imteaz, A study on selection of probability distributions for at-site flood frequency analysis in Australia. Natural Hazards, 69(3), 1803-1813(2013).

[13] B. K. Sathe, M. V. Khire, R. N. Sankhua, Flood Frequency Analysis of Upper Krishna River Basin catchment area using Log Pearson Type III Distribution. IOSR Journal of Engineering (IOSRJEN). 